\title{
AZ EURÓPAI KÖZÖS KUTATÁSI POLITIKA REGIONÁLIS DIMENZIÓJA
}

\author{
(Regional Dimension of the European Research Policy)
}

\author{
MIKITA JÓZSEF
}

Kulcsszavak:

kutatás fejlesztés innováció $(K+F+I)$ EU kohéziós politika EUKutatási keretprogram

Az Európai Unió (EU) 2007-2013 közötti programozási idôszaka költségvetésének elökészitése során nyilvánvalóvá vált, hogy az EU közös támogatási politikái között a kohézió és komplementaritás további erösítésre szorul. Kétségtelen, hogy a hatályban lévö szerzödések értelmében minden szakpolitika saját célrendszerrel rendelkezik, ugyanakkor világossá vált, hogy a hatékonyabb eredmények elérése érdekében szükségszerú az egyes iránymutatásokat logikus egységbe rendezni. Ezt az elképzelést erõsiti meg a lisszaboni stratégia (2000), illetve annak 2005-ös felülvizsgálata. A korábbiakhoz képest nagyobb hangsúlyt szükséges fektetni az egyes szektoriális politikák közötti interakciókra, növelni kell a közösségi cselekvés globális hatását.

Különösen jelentỏs szerepet játszik a lisszaboni célok teljesitésében a közös kohéziós illetve kutatásifejlesztési-innovációs politikák eszközrendszere. Elengedhetetlen, hogy a Strukturális Alapok és a Kutatási keretprogram Európa összes, így a kevésbé fejlett régiói számára is lehetőséget nyijtsanak a kutatásfejlesztési potenciál növelésére, továbbá szükséges, hogy az egyes pénzügyi eszközök kiegészitsék egymást és egyben erôsitsék pozitiv hatásukat.

\section{Bevezetés}

A kutatás-fejlesztés-innováció $(\mathrm{K}+\mathrm{F}+\mathrm{I})$ alapvetỏen azért fontos, hogy az EU képes legyen megfelelni az elötte álló kihívásoknak. Annak érdekében, hogy a kontinens lépést tudjon tartani legfóbb vetélytársaival, növelni kell a termelékenységet, a foglalkoztatási rátákat, amely hosszú távon egy valódi tudásalapú társadalom megteremtését teszi lehetóvé. A kutatás-fejlesztés megoldásokat kínálhat olyan globális problémák kezelésére, mint az éghajlatváltozás elleni küzdelem, vagy az energiaeróforrások optimálisabb felhasználása. A lisszaboni stratégia elsỏdleges célja egy olyan tudásalapú társadalom kiépítése, amelyben a $\mathrm{K}+\mathrm{F}+\mathrm{I}$ kiemelt szerephez jut. A közösségi $\mathrm{K}+\mathrm{F}$ töredezettségébỏl, illetve az erre szánt anyagi források korlátozottságából következően az EU olyan közös politikát dolgozott ki, melynek célja a többszintü (európai, nemzeti és szubnacionális) hálózatok kiépítése, valamint a méretgazdaságosság megteremtése (Korres-Chionis-Staikouras 2004).

A $\mathrm{K}+\mathrm{F}$ tevékenység leghatékonyabban regionális szinten értelmezhető, hiszen a fizikai közelség pozitívan hat a helyi szereplök közötti együttmüködések kialakítására. Három fontos elméleti megközelítés magyarázza a kutatás-fejlesztés egy adott térség gazdasági fejlődésére kifejtett pozitív hatását. Vhanevar Bush lineáris 
modellje szerint az alapkutatás előkészíti az alkalmazott kutatást, az utóbbi pedig az innováció elengedhetetlen feltétele és mozgatórugója. Az „innovációs rendszerek" teóriája az intézményi hálózatok szerepét emeli ki a $\mathrm{K}+\mathrm{F}+\mathrm{I}$-ben, ezeket tekintve a gyakorlati alkalmazások legfőbb generálójaként. A közgazdászok és geográfusok körében népszerú úgynevezett „spill-over” megközelítés az innováció pozitív hatásainak megosztására, és az ebből fakadó gazdasági fellendülésre helyezi a hangsúlyt (Pose-Crescenzi 2008).

Az egyes régiók gazdasági teljesítménye szempontjából létfontosságú, hogy a helyi döntéshozatal, a vállalkozási szféra mennyire képes a felhalmozott „tudásból”, a „tudományból" olyan versenyelỏnyt formálni, amely fenntartható és pozitív ösztönző lehet más régiók számára is. Az európai régiók történelmi hagyományaikból és eltérő gazdasági fejlettségükből következően nem képesek a tudást és technológiát ugyanolyan szintủ hatékonysággal befogadni, ami nyilvánvalóan meghatározza növekedési kilátásaikat, sok esetben tovább mélyítve a régiók között meglévő jelentős jólétbeli különbségeket.

Az EU kutatás-fejlesztés-innováció, valamint kohéziós politikái az alábbi prioritásokat tüzték ki célul a lisszaboni stratégia kontextusában:

- Közös Európai Kutatási Térség (EKT) megteremtése, amely elősegíti a kutatási potenciál növekedését az Unió összes régiójában, valamint csökkenti a fejlettségbeli különbségeket;

- A kutatás-fejlesztési és innovációs teljesítmény javítása, ezen keresztül a gazdasági növekedés és munkahelyteremtés elősegítése;

- Az európai vállalkozások támogatása, különös hangsúlyt fektetve a kis- és közepes vállalkozásokra (KKV);

- A 27 tagú Európai Unió gazdasági és társadalmi kohéziójảnak megerősítése a Közösség fenntartható fejlődésének érdekében;

- A nemzeti, regionális innovációs stratégiák kimunkálása (Competetive... 2007).

\section{A közösségi kohéziós politika és a $K+F$}

A 2007-2013 közötti időszakra kidolgozott operativ programokban a tagállamok kiemelt hangsúlyt fektetnek a kulcsfontosságú lisszaboni prioritások elérésére. A forráselkülönitési rendelkezések értelmében (earmarking) a régi tagországok (EU15) kötelesek a rendelkezésre álló források $60 \%$-át a konvergenciarégiók, illetve 75\%-át a regionális versenyképességi és foglalkoztatási régiók esetében a lisszaboni célokkal összefüggő finanszírozásra, tehát kutatás-fejlesztésre, illetve innovációhoz kapcsolódó célokra fordítani. Az újonnan csatlakozott tagállamok (EU12) maguk választhatják meg a célösszeget, ugyanakkor mindannyian részt vesznek a forráselkülönítés gyakorlatában (Member States... 2007). 
A lisszaboni stratégiával összefüggő célkitüzések már a korábbi programozási periódusokban is fontos szerepet játszottak a Strukturális Alapok elosztásánál, a tényleges számszerüsített előirányzat azonban kötelezővé teszi ezen célok teljesítését.

Az 1. táblázat a Strukturális Alapok 2007-2013 programozási tervidőszakra vonatkozó azon költségvetési tevékenységeit tartalmazza, melyek szervesen kapcsolódnak a tág értelemben vett kutatás-fejlesztés-innovációhoz. Ezek között négy nagyobb kategória különböztethető meg: Kutatás és technológiafejlesztés, innováció és vállalkozások; Információs társadalom; A munkavállalók, vállalkozások és vállalkozók alkalmazkodóképességének növelése; Az emberi tőke fejlesztése.

\section{TÁBLÁZAT}

Az innovációhoz kapcsolódó tevékenységek a Strukturális Alapokban, 2007-2013

(Innovation-related Activities in Structural Funds Programmes, 2007-2013)

\begin{tabular}{|c|c|}
\hline Kód & $\begin{array}{c}2007-2013 \\
\text { Kutatás és technológiafejlesztés, innováció }(K+F+I)\end{array}$ \\
\hline 1 & Kutatóközpontokban végzett kutatási és technológiafejlesztési tevékenységek \\
\hline 2 & $\begin{array}{l}\text { Kutatási és technológiafejlesztési infrastruktúra, adott technológiára szakoso- } \\
\text { dott központok }\end{array}$ \\
\hline 3 & Technológiaátadás és együttmủködési hálózatok fejlesztése \\
\hline 4 & Kutatási és technológiafejlesztési támogatás, különösen a KKV-k számára \\
\hline 5 & $\begin{array}{l}\text { Vállalatok és vállalatcsoportok számára nyújtott magas szintü támogatási } \\
\text { szolgáltatások }\end{array}$ \\
\hline 6 & A környezetbarát termékek és gyártási eljárások elömozdítása a KKV-k számára \\
\hline 7 & $\begin{array}{l}\text { A kutatáshoz és innovációhoz közvetlenül kapcsolódó vállalatokba történö } \\
\text { beruházás }\end{array}$ \\
\hline 9 & $\begin{array}{l}\text { A KKV-k kutatási, innovációs és vállalkozási tevékenységét ösztönzỏ egyéb } \\
\text { intézkedések }\end{array}$ \\
\hline 11 & Információs és kommunikációs technológiák \\
\hline 12 & Információs és kommunikációs technológiák (transzeurópai hálózatok - IKT) \\
\hline 13 & Szolgáltatások és alkalmazások az állampolgárok számára \\
\hline 14 & Szolgáltatások és alkalmazások a KKV-k számára \\
\hline 15 & A KKV-k számára az IKT-hez való jobb hozzáférést biztosító egyéb intézkedések \\
\hline 62 & $\begin{array}{l}\text { Az egész életen át tartó tanulási rendszerek és stratégiák kidolgozása a vállal- } \\
\text { kozásokban }\end{array}$ \\
\hline 63 & Az innovatív és termelékenyebb munkaszervezés kidolgozása és terjesztése \\
\hline 64 & $\begin{array}{l}\text { Az ágazatok és vállalkozások átszervezéséhez kapcsolódó konkrét foglalkozta- } \\
\text { tási, képzési és támogatási szolgáltatások kialakítása }\end{array}$ \\
\hline 68 & Az egyéni vállalkozáshoz és új vállalkozások indításához nyújtott támogatás \\
\hline 74 & Az emberi eröforrások fejlesztése a kutatás és innováció terén \\
\hline
\end{tabular}

Forrás: Infoview (2008).

Megállapítható, hogy az előbbi tevékenységi lista mennyiségileg és minőségileg egyaránt jelentősen kibővült az előző, 2000-2006-os tervezési időszakhoz képest, amikor összesen 13, konkrétan az innovációhoz kapcsolódó tevékenységi területet jelöltek ki, és finanszírozhattak a tagállamok a kohéziós politikára szánt költségvetésböl. 
2005-ben a Hampton Courtban tartott csúcsértekezletet követően kijelölt független szakértői csoport (Aho csoport, Esko Aho Finnország korábbi miniszterelnöke nyomán) a 2006. tavaszi Európai Tanács elött ismertette az Európai Bizottsággal arra vonatkozó tanácsait, hogy a felülvizsgált lisszaboni stratégiával összefüggésben az EU kutatási és innovációs teljesítményének megerösítése milyen módon gyorsitható fel. Külön kiemelte a Strukturális Alapok fontosságát, és támogatta az új programozási időszakra lefektetett azon elképzelést, melynek értelmében a tagállamok kohéziós költségvetésük meghatározott százalékát fordítsák innovációs célokra (Creating... 2006).

Az Unió tagállamai az Operatív Programok elỏkészítésekor, a kohéziós célok függvényében, illetve a kötelező forráselkülönítést figyelembe véve meghatározzák saját célrendszerüket, rögzítik a támogatni kívánt tematikákat. A 2. táblázat tagállamra lebontva tartalmazza a közösségi támogatás 2007-2013-as időszak kutatásfejlesztés-innovációra fordítandó abszolút és relatív pénzösszegeit.

$\mathrm{Az}$ innovációt tágabban értelmezve az EU15 esetében a legjobb teljesítménnyel Dánia büszkélkedhet, a kohéziós politikára szánt összeg közel 70\%-át fordítja erre a célra. Szintén átlépik az 50\%-os küszöböt, tehát a kiválóan teljesitők közé sorolhatók az alábbi tagállamok: Finnország (60,2\%), Ausztria (57,9\%), Svédország (51,9\%), Hollandia (51,1\%), valamint az Egyesült Királyság (50,1\%). A régi tagállamok közül Görögország teljesít a legrosszabbul, teljesítménye alig haladja meg a $20 \%$-ot. Az újonnan csatlakozott tagországok közül (EU12) Szlovénia a legjobban teljesitő $(31,4 \%)$, míg Bulgária és Málta rendelkezik a legalacsonyabb százalékos aránnyal (mindkét ország esetében 14,9\%). Magyarország a tervezési dokumentumokban a rendelkezésre álló pénzösszeg 21,7\%-át forditja a kutatás-fejlesztés-innováció finanszírozására, amellyel kevéssel az EU12 átlag alatt (22,9\%) helyezkedik el, ugyanakkor jelentősen elmarad az összes tagállamot aggregáló átlagértéktől ( $28,9 \%)$.

A szigorú értelemben vett kutatás-fejlesztés-innováció esetében az EU15-ök között a legmagasabb hányadossal Luxemburg rendelkezik (34,2\%), míg a leggyengébb teljesítmény ebben az esetben is Görögországé (7,3\%). A kohéziós költségvetésük jelentős hányadát költik K+F-re a következö EU15-ös tagállamok: Ausztria (31\%), Finnország (29,3\%), Svédország (24,9\%), Egyesült Királyság $(22,8 \%)$, valamint Olaszország (22\%). Az EU12-k közül kiemelkedik Szlovénia (23,8\%), Észtország $(19,2 \%)$, valamint Lettország $(16,4 \%)$ teljesítménye. Az országcsoport legrosszabb teljesítménye Bulgáriához és Romániához füződik ( $5,8 \%$ mindkét tagállam esetében). Hazánk $(8,7 \%)$ az újonnan csatlakozó tagállamok átlaga $(11,9 \%)$ alatt teljesít. 


\section{TÁBLÁZAT}

A Strukturális Alapokból innovációs célra forditott közösségi támogatás, 2007-2013 (Community Spending on Innovation-related Activities from the Structural Funds,

\begin{tabular}{|c|c|c|c|c|c|c|c|}
\hline \multirow[b]{2}{*}{ Ország } & \multirow[b]{2}{*}{$\begin{array}{c}\text { Közösségi } \\
\text { Támoga- } \\
\text { tás, } \\
\text { millió } \\
\text { euró }\end{array}$} & \multirow[b]{2}{*}{$\begin{array}{l}\text { Innovációs } \\
\text { célra fordí- } \\
\text { tott Közös- } \\
\text { ségi Támo- } \\
\text { gatás, } \\
\text { millió euró }\end{array}$} & \multirow[b]{2}{*}{$\begin{array}{l}\text { Inno- } \\
\text { váció } \\
(\%)\end{array}$} & \multicolumn{4}{|c|}{ Ezen belül: } \\
\hline & & & & $\begin{array}{c}K+F \\
(\%)\end{array}$ & $\begin{array}{c}\text { Vállal- } \\
\text { kozások } \\
(\%)\end{array}$ & $\begin{array}{l}\text { Infor- } \\
\text { mációs } \\
\text { társa- } \\
\text { dalom } \\
(\%)\end{array}$ & $\begin{array}{l}\text { Emberi } \\
\text { tőke- } \\
\text { fejlesz- } \\
\text { tés }(\%)\end{array}$ \\
\hline Ausztria & 1204,5 & 697,2 & 57,9 & 31,0 & 12,8 & 1,5 & 12,5 \\
\hline Belgium & 2063,5 & 917,6 & 44,5 & 15,3 & 16,5 & 0,3 & 12,4 \\
\hline Bulgária & 6673,6 & 994,4 & 14,9 & 5,8 & 5,0 & 1,1 & 3,0 \\
\hline Ciprus & 603,5 & 148,2 & 24,5 & 10,2 & 10,0 & 2,5 & 1,8 \\
\hline $\begin{array}{l}\text { Cseh Köz- } \\
\text { társaság }\end{array}$ & 26302,6 & 6409,7 & 24,4 & 14,3 & 2,7 & 3,5 & 3,8 \\
\hline Dánia & 509,6 & 355,4 & 69,8 & 31,1 & 5,7 & 4,9 & 28,1 \\
\hline $\begin{array}{l}\text { Egyesưlt } \\
\text { Királyság }\end{array}$ & 9890,9 & 4976,4 & 50,3 & 22,8 & 10,4 & 3,2 & 14,0 \\
\hline Észtország & 3403,5 & 885,5 & 26,0 & 19,2 & 2,7 & 2,2 & 1,9 \\
\hline Finnország & 1596,0 & 961,5 & 60,2 & 29,3 & 11,5 & 8,9 & 10,6 \\
\hline $\begin{array}{l}\text { Francia- } \\
\text { ország }\end{array}$ & 13449,2 & 4608,4 & 34,3 & 16,7 & 6,4 & 3,9 & 7,2 \\
\hline $\begin{array}{l}\text { Görög- } \\
\text { ország }\end{array}$ & 20210,3 & 4138,0 & 20,5 & 7,3 & 3,4 & 6,9 & 2,9 \\
\hline Hollandia & 1660,0 & 847,5 & 51,1 & 17,0 & 5,1 & 4,0 & 24,9 \\
\hline Írország & 750,7 & 201,1 & 26,8 & 15,3 & 5,6 & 2,1 & 3,8 \\
\hline $\begin{array}{l}\text { Lengyel- } \\
\text { ország }\end{array}$ & 65221,9 & 15790,3 & 24,2 & 13,1 & 4,5 & 4,2 & 2,4 \\
\hline Lettország & 4530,4 & 1067,0 & 23,6 & 16,5 & 2,3 & 3,8 & 1,1 \\
\hline Litvánia & 6775,5 & 1672,8 & 24,7 & 14,6 & 4,0 & 2,9 & 3,2 \\
\hline Luxemburg & 50,5 & 19,0 & 37,7 & 34,2 & 1,0 & 2,5 & \\
\hline $\begin{array}{l}\text { Magyar- } \\
\text { ország }\end{array}$ & 24921,1 & 5369,6 & 21,5 & 8,7 & 7,6 & 3,0 & 2,3 \\
\hline Málta & 840,1 & 125,0 & 14,9 & 6,8 & 2,6 & 3,2 & 2,3 \\
\hline $\begin{array}{l}\text { Német- } \\
\text { ország }\end{array}$ & 25488,6 & 11289,4 & 44,3 & 18,0 & 17,8 & 1,3 & 7,2 \\
\hline $\begin{array}{l}\text { Olasz- } \\
\text { ország }\end{array}$ & 27845,0 & 9888,4 & 35,5 & 22,0 & 4,5 & 5,3 & 3,7 \\
\hline Portugál ia & 21411,6 & 6171,2 & 28,8 & 16,5 & 7,0 & 2,9 & 2,4 \\
\hline Románia & 19213,0 & 3441,2 & 17,9 & 5,8 & 5,4 & 1,8 & 4,9 \\
\hline $\begin{array}{l}\text { Spanyol- } \\
\text { ország }\end{array}$ & 34657,7 & 11488,9 & 33,1 & 16,3 & 9,0 & 2,8 & 5,0 \\
\hline Svédország & 1626,1 & 843,5 & 51,9 & 24,9 & 11,8 & 4,4 & 10,8 \\
\hline Szlovákia & 11360,6 & 2666,1 & 23,5 & 10,5 & 1,9 & 9,5 & 1,5 \\
\hline Szlovénia & 4101,0 & 1289,0 & 31,4 & 23,8 & 3,7 & 2,1 & 1,9 \\
\hline $\begin{array}{l}\text { Határokon } \\
\text { átnyúló } \\
\text { együttmü- } \\
\text { ködés }\end{array}$ & 7823,8 & 2121,3 & 27,1 & 16,0 & 2,9 & 6,4 & 1,9 \\
\hline TOTAL & 344184,9 & 99383,6 & 28,9 & 14,5 & 6,4 & 3,8 & 4,2 \\
\hline EU 12 & 173947,0 & 39858,7 & 22,9 & 11,9 & 4,5 & 3,7 & 2,8 \\
\hline EU 15 & 162414,1 & 57403,6 & 35,3 & 17,3 & 8,6 & 3,7 & 5,8 \\
\hline EU 27 & 336361,1 & 97262,3 & 28,9 & 14,5 & 6,5 & 3,7 & 4,2 \\
\hline
\end{tabular}

Forrás: Infoview (2008). 


\section{A kutatási keretprogram a területi kohézió szolgálatában}

Az Európai Unió $\mathrm{K}+\mathrm{F}$ és innovációs politikájának legföbb eszközrendszere a több éven keresztül futó keretprogramok, melyek az 1980-as évektől kezdve egyre nagyobb költségvetéssel rendelkeznek. A támogatási összeg 2013-ra elérheti a 9 milliárd eurót, amely 75\%-kal meghaladja az elöző programozási időszak utolsó évében nyújtott támogatást (Energising... 2007).

A keretprogramokban eleinte a regionális dimenzió nem kapott különösebb jelentöséget. A projektekben való részvétel nagymértékben függ a helyi adottságoktól, hiszen a részvételt leginkább a $\mathrm{K}+\mathrm{F}$ létesítmények, felsőoktatási intézmények, illetve a vállalati szféra koncentráltsága határozza meg. Ilyen módon az elmaradottabb régiók rendkívüli hátrányt szenvedtek, és nem profitálhattak a keretprogram nyújtotta lehetőségekböl. Ennek következménye, hogy a korábbi első célkitüzésbe tartozó régiók a Hatodik keretprogram (2002-2006) összes résztvevőjének mindössze 18\%-át adták (Healy-Roy 2006).

Időközben az egymást követő keretprogramokban mindinkább felismerték az EU $\mathrm{K}+\mathrm{F}$ politikájának területi dimenzióját. 2001-ben a Bizottság közleményt adott ki, amelyben hangsúlyozta a gazdasági élet regionális és helyi szereplöinek döntő szerepét az Európai Kutatási Térség (EKT) megteremtésében, valamint kiemelte, hogy az EKT-ét az Unió valamennyi régiója számára elérhetővé kell tenni (The Regional... 2001).

\section{TÁBLÁZAT}

EU 7. Keretprogram , Kapacitások” specifikus program, 2007-2013

(EU RTD 7th Framework Programme, Capacities Specific Programme, 2007-2013)

EU 7. Keretprogram 2007-2013

\begin{tabular}{|c|c|}
\hline Specifikus program & Költségvetés (millió euró) \\
\hline Kooperáció & 32413 \\
\hline Ötletek & 7510 \\
\hline Emberek & 4750 \\
\hline Kapacitások & 4097 \\
\hline JRC & 1751 \\
\hline Összesen & 50521 \\
\hline \multicolumn{2}{|c|}{ Kapacitások } \\
\hline Intézkedés & Költségvetés (millió euró) \\
\hline Kutatási infrastruktúra & 1715 \\
\hline $\begin{array}{l}\text { Kis- és középvállalkozások javát szolgáló } \\
\text { kutatás }\end{array}$ & 1336 \\
\hline Tudás Régiói & 126 \\
\hline Kutatási potenciál & 340 \\
\hline Nemzetközi együttmüködés & 180 \\
\hline Tudomány a társadalomban & 330 \\
\hline $\begin{array}{l}\text { A kutatási politikák koherens fejlesztésé- } \\
\text { nek támogatása }\end{array}$ & 70 \\
\hline Összesen & 4097 \\
\hline
\end{tabular}

Forrás: CORDIS DG RTD (2007). 
A jelenleg futó hetedik keretprogram (2007-2013) „Kapacitások” specifikus programján belül 2 tevékenységi terület van közvetlenül összhangban a közösségi kohéziós politika célrendszerével (3. táblázat).

A „tudás régiói” (Regions of Knowledge) alapvető feladata erősíteni az európai régiók kutatási potenciálját, különösképpen a regionális hatóságokat, egyetemeket, kutatóközpontokat és vállalkozásokat tömöritő „kutatásorientált regionális csoportosulások" (regionális klaszterek) ösztönzésének és fejlódésének támogatása révén. A 2003-ban kísérleti jelleggel indult kezdeményezés lehetővé teszi a régiók számára a $\mathrm{K}+\mathrm{F}$-be való befektetési potenciál megerösitését, továbbá ösztönzi az új regionális klaszterek kiépítését, ezzel is hozzájárulva az európai régiók jóléti színvonalának emelkedéséhez (Capacities PART3... 2007).

A „kutatási potenciál” (Research Potential) tevékenység az EU konvergencia- és legkülső régióiban ösztönzi a meglévő vagy kialakulóban lévő kiválóságok fejlesztését, segíti ezen régiók felkészülését a közösségi kutatási tevékenységben való sikeres részvételre. A kibövült 27 tagú EU teljes kutatási potenciáljának felszabadításának érdekében különös figyelmet szükséges szentelni azon régiókra, amelyek elmaradottságukból következően nem képesek kiaknázni a bennük rejlö lehetöségeket. A cselekvés nagymértekben épít olyan korábbi és jelenlegi intézkedésekre, mint az ötödik keretprogramból ismert, az akkori csatlakozó és tagjelölt országok számára létrehozott európai kiválósági központok és a tudásátadást célzó Marie Curie ösztöndíjak (Capacities PART4... 2007).

\section{Lehetséges szinergizmusok a közös kutatási-fejlesztési-innovációs $(K+F+I)$ politika és a kohéziós politika között}

Az Európai Unió kutatás-fejlesztés-innovációs, valamint kohéziós politikái különböző módon járulnak hozzá a foglalkoztatás és a gazdasági növekedés közös céljainak eléréséhez. A kutatáspolitika a nemzetközi szintủ kiválóságok segítésére fókuszál, az innováció legfontosabb célja, hogy a felhalmozott tudást üzleti lehetöségekké alakítsa, gyakorlati megoldásokat biztosítson a társadalom számára. A kohéziós politika esetében a szolidaritás, a méltányosság és az igazságosság elvei alapján az elsödleges cél a regionális egyenlötlenségek, fejlettségbeli különbségek csökkentése, valamint az elmaradottabb régiók felzárkóztatása (Korres-ChionisStaikouras 2004).

Fontos megemlíteni, hogy a $\mathrm{K}+\mathrm{F}+\mathrm{I}$, illetve kohéziós politikáknak eltérố rendelkezések szolgálnak jogalapul az alapszerződésekben. A legáltalánosabban értelmezett cél mindkét eszközrendszernél azonos (a foglalkoztatás és gazdasági növekedés erősítése), ugyanakkor a speciális célkitüzések a Szerződéssel összhangban kerültek meghatározásra. Az eltérö jogalapból következỏen a $\mathrm{K}+\mathrm{F}+\mathrm{I}$ politika finanszírozási eszközei tématerületekre irányulnak, míg a kohéziós politika esetében a földrajzi értelemben vett terület (a régió) a legfontosabb alapegység. A K+F eszközrendszere 
tehát tematikus szakosodást hoz létre, míg a regionális politika integrált szemléletet eredményez (Energising... 2007).

A kutatási keretprogramok alapvetően európai szintủ, tehát transznacionális, versenyeztetésen alapuló pályázati felhívásokkal müködnek. A pályázatok elbírálásában a Bizottság által kiválasztott független szakértők vesznek részt, a pályázatok kiválasztásának egyetlen kritériuma a kiválóság, vagyis nem léteznek nemzeti kvóták. A kohéziós politika végrehajtása a Bizottság és a tagállamok közös kompetenciája, amely a többszintü kormányzás (multi-level governance) elveit követi. A kiválasztási folyamat elsösorban a regionális partnerségen alapul. Ezen támogatási eszközök összehangolt felhasználását az is megkönnyiti, hogy a jelenleg futó programok időben teljes egészében lefedik egymást (2007-2013) (Policy... 2006).

A koherens $\mathrm{K}+\mathrm{F}+\mathrm{I}$ támogatási stratégia kimunkálásában a legnagyobb feladat a tagállamokra és a régiókra hárul, hiszen ezek tudják megítélni a beruházási igényeket és felvázolni az egyes projekteket. A közpénzekkel való hatékony és eredményes gazdálkodás értelmében nincsen mód arra, hogy ugyanazon támogatható költséget különböző közösségi forrásból fedezzenek, tehát nem lehetséges a „dupla finanszírozás" (double financing).

A „társfinanszírozás" (co-financing) elve azt jelenti, hogy az EU támogatási eszközei az esetek nagy többségében nem helyettesíthetik a tagállami, regionális, avagy a pályázó entitás (kutatóintézet, KKV, helyi hatóság) hozzájárulását. Pontos szabályok léteznek erre vonatkozóan mind a Strukturális Alapok, mind pedig a Kutatási keretprogram esetében. A Strukturális Alapok 2007-2013 időszakra vonatkozó szabályzata világosan kimondja, hogy nincs lehetőség a társfinanszírozásra szánt öszszeget más EU-s pénzügyi eszközböl fedezni. Ugyanez az elv vonatkozik a Kutatási keretprogram végrehajtására is. Lehetöség nyilik ellenben arra, hogy a Strukturális Alapok, a Kutatási keretprogram és más további uniós források ugyanazon kutatásiinnovációs projekt különböző aspektusait vagy fázisait támogassák, feltéve, hogy ez megfelel az adott finanszírozási forrás támogatási kritériumának. Ezt nevezzük „kiegészítö" finanszírozásnak (complementary financing) (Practical... 2007).

Rendkívül fontos ugyanakkor, hogy a szinergiák ne kizárólag a projektfinanszírozásra koncentráljanak, a kutatási és innovációs kapacitások kiépítésében és fejlesztésében is elengedhetetlen a komplementaritás. Ennek formája a Bizottság által is gyakran emlegetett tudásátadás (knowledge transfer). Mindkét közösségi támogatási rendszer lehetőséget nyújt arra, hogy az Európai Unió régiói megosszák egymással kutatási és innovációs tudásukat. A bevált gyakorlati megoldások régióközi partnerségek, illetve az európai szintủ nyílt koordináció (open method of coordination) keretében való megosztása fontos szerepet játszik az egész EU kutatási és innovációs teljesitményének javításában.

A közelmúltban számos tanácsadói testület és intézményi szereplö foglalkozott az eszközrendszerek komplementaritásának kérdésével. Az Európai Unió Tudományos és Múszaki Bizottsága (CREST) iránymutatásokat fogadott el, az Európai Kutatási Tanácsadó Bizottság (EURAB) közleményt adott ki a témában. Az Európai Parlament ITRE bizottságának megbízásából 2006-ban tanulmány készült az egyes 
pénzügyi eszközök lehetséges optimális felhasználásáról. A testület megerősítette zárójelentésében, hogy a lisszaboni célok mielöbbi teljesítésének érdekében a komplementaritás elvének hatékonyabb alkalmazása javasolt a kétféle pénzügyi eszközrendszer végrehajtásában. Kiemelte, hogy az eredményesebb működés elérésében a kutatási keretprogram és a kohéziós politika végrehatásában részt vevö nemzeti és regionális szereplők között hatékonyabb együttmüködés és koordináció szükséges (Competetive... 2007).

\section{Következtetések}

Az Európai Unió számára jelenleg az egyik legfontosabb kihívás a lisszaboni stratégia által lefektetett célok teljesítése, különös tekintettel a gazdasági növekedés és munkahelyteremtés kérdéseire. Ezen célok elérésében a szakpolitikák közül kiemelt jelentösége van a kutatás-fejlesztés-innovációnak, valamint a közös kohéziós politikának.

A fenntartható fejlődésen alapuló európai modell müködésének alapfeltétele, hogy Európa kiváló kutatási és innovációs bázissal rendelkezzen. A kohéziós politika ugyanakkor segítheti az egyes régiókat a kutatási és innovációs kapacitás kiépítésében, az innováció ösztönzésében és támogatásában, valamint a bevált gyakorlati megoldások terjesztésében.

Annak érdekében, hogy az elmaradottabb régiók szereplői sikeresen vehessék fel a versenyt Európa fejlettebb térségeivel a Keretprogram „Kooperáció” fejezetében, elengedhetetlen a kutatási potenciál egy meghatározott fejlettségi szintje. Ebben nyújthat segítséget a keretprogram „Kapacitások” fejezete, mely a multinacionális szemléletmód ösztönzésével továbbfejleszti ezt a „kapacitást”. A Strukturális Alapok pénzügyi eszközei a keretprogram eszközrendszere által azonositott igények kielégítésének támogatásában alkalmazhatók.

A szakpolitikák elökészítésében, végrehajtásában részt vevố európai, nemzeti és regionális szereplöknek törekedni kell arra, hogy szinergiák álljanak fenn a gazdasági növekedés és a foglalkoztatás megerösítésére létrehozott pénzeszközök között, továbbá pozitív összhatásuk a lehetỏ legmagasabb szintet érje el.

\section{Irodalom}

Capacities, PART 3 Regions of Knowledge - Work Programme 2008. C(2007) 5759. (2007) Commission of the European Communities, Brussels.

Capacities, PART 4 Research Potential - Work Programme 2008. C(2007) 5759. (2007) Commission of the European Communities, Brussels.

Competetive European regions through research and innovation. (2007) COM(2007) 474 final, Commission of the European Communities, Brussels.

CORDIS, DG RTD. (2007) European Commision, Brussels. http://cordis.europa.eu/fp7/home_en.html Creating an Innovative Europe. (2006) Independent Expert Group on R\&D and Innovation appointed following the Hampton Court Summit and chaired by Mr. Esko Aho. Office for Official Publications of the European Communities, Luxembourg. 
Energising Europe's Knowledge Triangle of Research, Education and Innovation through the Structural Funds. (2007) Final Report. European Research Advisory Board, Brussels.

Healy, A.-Roy, S. (2006) Where Does the Budget Go? Exploring the Territorial Dimension of EU R\&D Policy. - Scienze Regionali. 2. 111-134. o.

Infoview. (2008) DG Regional Policy. Commission of the European Communities, Brussels.

Korres, G.M.-Chionis, D.-Staikouras, C. (2004) Regional systems of innovation and regional policy in Europe. - Regional and Sectorial Economic Studies AEEADE. 1.25-44. o.

Member States and Regions delivering the Lisbon strategy for growth and jobs through EU cohesion policy, 2007-2013. (2007) COM(2007) 798 final, Commission of the European Communities, Brussels.

Practical Guide to EU funding opportunities for research, development and innovation; Synergies in funding opportunities between: $7^{\text {th }}$ Framework Programme for Research. (2007) Commission of the European Communities, Brussels.

Policy Department Economic and Scientific Policy. (2006) Synergies between the $7^{\text {th }}$ Research Framework Programme, the Competitiveness and Innovation Framework Programme and the Structural Funds. Network for European Techno-Economic Policy Support, Brussels.

Pose, A.R.-Crescenzi, R. (2008) Research and Development, Spillovers, Innovation Systems and the Genesis of Regional Growth in Europe. - Regional Studies. 1. 51-67. o.

The Regional Dimension of the European Research Area. (2001) COM(2001) 549 final, Commission of the European Communities, Brussels. 